\title{
Some Aspects of Criminal Participation
}

\author{
Silviu-Ștefan Petriman \\ Master of Science in Criminal Justice, "Dimitrie Cantemir" Christian University of Bucharest, Romania, \\ silviupetriman@yahoo.com
}

\begin{abstract}
In the social life, human activity may be performed by one person, but in some other people can contribute to the same activity. If this human activity is characterized by committing an act provided by the Criminal Law, and other persons are contributing to this deed, we are in the presence of participation to the commission of an offense under Criminal Law. In other words, we have a plurality of people who commit a crime stipulated by the criminal law. So who directly commits the deed directly is the author and the others are participants. In order to be in the presence of a criminal participation, it is not enough that other people participate, but the participants need to be animated by a common will, together with the author, to commit the crime provided by the Criminal Law. Another condition is that the crime provided by the Criminal Law has been committed by a larger number of persons than necessary, according to the nature of the act otherwise we will have either a plurality constituted either by natural plurality. The Romanian Criminal Law incriminates this form of plurality of offenders (also called occasional) in Title II, Chapter 6, entitled "The Author and the Participants."
\end{abstract}

KEYWORDS: accomplice, author, co-author, criminal participation, instigator

\section{Introduction}

The plurality of subjects active in criminal matters should be analyzed in relation to a specific criminal offense prescribed by law, concerned with a specific offense. In other words, in terms of plurality of offenders (criminals), the idea of plurality on the perpetrator, and the idea of unity concerns the deed (offense) (Molnar 2001, 8).

The plurality of offenders (concursus plurium ad idem delictum) involves actual contributions, belonging to several persons acting with a common will to perpetrating the deed acts provided for by the criminal law. The plurality of offenders changes into a plurality of offenders if it acts with the form of guilt required by law for the existence of the offence.

The Romanian legislator no longer relates to the offense, but to the deed, so within the holding not only his own, but also the improper form is included (Lefterache 2016, 395).

\section{Criminal shareholding. Notion}

Criminal participation or occasional plurality of criminals means the situation in which the common will of more persons committing a deed provided by criminal law commission of a criminal law has contributed more than one person to the nature of that act or according to the will of the legislator (Mitrache and Mitrache 2014, 364).

The need to sanction participants in committing an act provided by criminal law has been explained by the elaboration of several theories, such as the causal theory, the corruption theory, and the theory of participation in an illicit deed. So, according to doctrine (Streteanu and Niţu 2018, 218), it is provided that according to causal theory, sanctioning the instigator and the complicit would be justified by the fact that their actions or inactions are causal in relation to the result produced.

The illicit nature of the act of the instigator and the complicit derives directly from the damage to the social value that it has caused or supported. From this perspective, the author's conduct appears as the means by which the participant's causal contribution is channeling a greater distance from this contribution of the produced result, with the consequence of lower sanctionability.

From the perspective of the theory of corruption (the theory of participation in imputability), they start from the idea that the participant must be sanctioned because he is the one who corrupted the author, making him violate the legal order.

Neither this theory is supported by current legislation. The penalty applied to the instigator depends primarily on his behavior, not on the degree of imputation of the author, or on the extent to 
which he was previously socially integrated, and the extent to which the instigator influenced him negatively.

The theory of participation in an illicit deed enjoys the greatest audience in the doctrine. According to this theory, the basis of sanctioning the instigator and the complicit is given by his involvement in committing an illicit deed by another person. Thus, the participant does not realize the typical nature of a deed described in the special part of the penal code or in the special legislation, does not violate the prohibition established by the norm of incrimination, but the prohibition to determine the commission of a typical act or to support its commission, as established by Art. 47 and 48 of the Criminal Code.

Thus, the illicit behavior of the instigator or complicity is determined first and foremost by the illicit act to which they contribute. Thus, a justifiable cause of the author's deed, removing the illicit nature, also produces its effects on the participants. Similarly, in the case of offences with a special subject, it is possible to retain the participation in those who do not have the quality required by the rule of criminality, because they do not realize the content of this rule, but the one which defines complicity or instigation.

\section{Conditions for the existence of criminal participation}

a) A crime prescribed by criminal law must be committed;

b) The act is to be committed in cooperation by two or more persons;

c) All participants should be animated by a common will to commit the crime prescribed by the criminal law;

d) The act committed to fulfill the features and content of the offence for at least one of the participants;

In order to fulfill the condition of committing an act provided by criminal law, it is sufficient to commit any of the acts that the law punishes as a crime committed or attempted, as well as participation in their committing as coauthor, instigator or accomplice according to art. 174 Criminal Code (Lefterache 2016, 403).

For the second condition for the cooperation of two or more persons to commit the offense provided by the criminal law, it is sufficient for one of these persons to fulfill the conditions for being an active subject of the offense and to act intentionally.

Concerning the third condition, the participants are animated by a common will to commit the act provided by the criminal law, it is of the essence of the criminal participation.

The existence and character of criminal participation are determined by the existence of a dual psychological link between the participants. On the one hand, there is a common will to cooperate in committing the same act provided by the criminal law, and on the other hand there is the common goal or result pursued by the participants in committing the deed. Of the two psychical ties, only the first is essential for the existence of the participation, because without the common will to cooperate in committing the deed, criminal participation cannot exist.

Finally, for the fourth condition to be also fulfilled, the contribution of participants to the committing of the deed has criminal relevance only in the situation when the deed is an offense for one of the participants.

\section{The modalities of criminal participation}

The modalities resulting from the legal regulation of criminal participation are as follows (Grădinaru 2017, 64):

1) By mental attitude:

a) Own or perfect participation - all participants contribute to committing the offense with the same guilt.

b) Improper or imperfect participation - some participants act intentionally and others, whether guilty or without guilt.

2) By nature of the contribution: 
a) Authored and co-authored - the contribution consists in direct and direct execution of the act, namely committing the acts that constitute the material element of the objective side of the offense.

b) Instigation-the contribution consists in determining another person (transmitting the judgment) to the offense.

c) Complicity-aiding or facilitating the commission of the offense

3) According to the importance of the contribution:

a) The main share is characterized by direct and direct execution of the acts of execution, being specific to the authors and co-authors

b) Secondary participation is characterized by contributions that do not consist of acts of direct and direct execution. This contribution is specific to instigators or accomplices. It should be noted that the activity of instigators is more important than that of accomplices.

4) According to the moment when they contributed:

a) A previous contribution is made before the perpetuation of the act by the author. Only the instigator and the accomplice can have contributions prior to the act.

b) Concurrent contribution is made during the commission of the offense. Concomitant constraints may have concomitant co-authors or accomplices.

\section{Author and Co-author}

The author is the person who directly commits an act provided for by the criminal law (art. 46 par. (1) Criminal Code).

According to the norm of incrimination, the author commits acts of execution. Without the author we cannot talk about the other forms of participation. The author is the main executor of the deed stipulated by the criminal law, but in some situations he acts together with other participants who have secondary contributions. Whether the perpetrator commits the offense by himself, or takes it alongside an instigator or an accomplice, an author's activity has a necessary character, without which the perpetration of the crime (its existence) is unthinkable (Molnar 2001, 72).

From the legal regulation, namely from the title of chapter 6, "The Author and the Participants", it is pointed out that the author is not a participant in the commission of the offense.

In the case of his own criminal participation, the perpetrator carries out the deed only with a direct or indirect intent or with praterintentia, and in the case of an improper criminal participation, the author commits the act guilty or not guilty (Udroiu 2017, 274).

The co-author is the person who commits the same act as provided by the criminal law directly (Article 46, paragraph 2)

In order to be co-authored, certain conditions must be met:

a) Indivisible unit of actions of several perpetrators

b) Subjective cooperation of the perpetrators. If the norm of criminality requires a certain quality of the author, it is necessary for the coauthor to have this quality.

However, the actions of the co-authors must not necessarily be identical to those of the author, it is important that the unity of the actions be indivisible (for example: if two persons, following an agreement commit a robbery offense, but only one of them exerts violence, and the second one steals the goods, we will be in the presence of a crime committed in the form of a co-authoring).

\section{Offenses that cannot be committed in the form of a co-authoring}

According to the material element of the offense, the offenses that involve inaction (own omissive offenses) cannot be committed in the co-authoring, when the obligation to perform an action, an activity to shift out of passivity, is personal (eg.) If the obligation is imposed on a collective body, in case of failure to fulfill this obligation, the members of the collective will be co-authors of the deed (Mitrache and Mitrache 2014, 370).

No offense involving a qualifying subject (manager, official) can be committed unless the perpetrators have the quality required by law.

Co-authoring is also not possible for offenses committed in his own person (false testimony) 
Offenses that do not allow co-authoring, as a form of criminal participation, however, allow for other forms of participation-instigation and complicity, which otherwise do not know constraints.

\section{Instigation}

According to Article 47 of the Penal Code, the instigator is the person who deliberately causes another person to commit a crime prescribed by the criminal law. The instigator's activity precedes the phases of the author's crime, for the instigation consists in the fact that the author of the criminal idea conveys the idea to another person, under the conditions and means that make that person acquire and execute it.

\section{Conditions for the existence of the instigation}

a) There is an activity of determining when committing an act provided by the criminal law. Instigation can be done by any means, regardless of whether they are licit or illicit.

b) The determination is made intentionally

The intent that characterizes the activity of the instigator usually takes the form of direct intent, but the hypothesis of instigating acts committed with potential intent is also excluded. Given the adventitious nature of the instigation, in order for this form to be retained, the determining activity must produce effects, that is, effectively lead to the commission of the typical deed in which it was instigated in consumed form or at least in the form of the incriminated attempt.

\section{Complicity}

According to Article 48C, the accomplice is the person who intentionally facilitates or assists in any way the commission of a criminal law act or promises, before or during the commission of the deed, that he will receive, acquire or transform the goods, or that he will help the perpetrator to hinder or punish the prosecution, trial, or execution of the punishment, even if the promise is not fulfilled after the act has been committed (Udroiu 2017, 281).

\section{Forms of complicity}

Depending on the nature of the acts of relief or assistance, the complicity may be material or moral. In the material complicity, the activity of facilitating or helping consists in the material support of the author. Eg: the complete delivery of the gun of the perpetrator to kill the rival that the perpetrator actually uses the material provided by the accomplice.

In moral complicity, helping or facilitating activity consists of a moral support, a psychological support of the author, in order to strengthen his / her criminal rehabilitation. Eg: the compliments give assurances to the perpetrator that he / she will provide his / her stall to deposit the stolen goods.

\section{Improper participation}

Improper participation can arise through intention-guilt or intentional-no guilt.

The intention-fault mode provides that the co-author, the instigator and the accomplice shall be punished with the punishment stipulated for the intentional act, and the author shall be punished with the punishment stipulated by the law for the culpable deed. Where the law does not provide for the sanction of fault, the perpetrator will be acquitted.

The mode of intention-lack of guilt presupposes that the author of the deed is in any of the cases of impropriety at the time of the act, in which case he will be acquitted and the instigator or the accomplice will be punished with the punishment provided by the law for the fifth offense.

\section{Conclusions}

It should be borne in mind that the role of criminal law is to regulate and sanction by law those situations that reflect an objective reality and pose a threat to society. At the same time, it is necessary to discipline the addressees of the criminal law, in order to prevent and discourage the commission of crimes and, moreover, participation in the commission of such deeds. Thus, by criminalizing the participation in the 
commission of a crime, it is attempted to discourage the persons from participating in some antisocial deeds. Thus, the legislator refers to committing an act provided by the criminal law and not to an offense, thus including improper participation. There are few situations when major people use minors who are not criminally responsible for committing crimes. In some instances, instigators or accomplices are punished more severely as the perpetrator of the deed, because in the individualization of punishment, the contribution of each person to the deed will be taken into account, and the personal circumstances of each participant also.

\section{References}

Grădinaru, D. 2017. Institutions of Criminal Law. Bucharest: C.H.Beck Publishing House. Law no 286/2009 - Criminal Code, published in Official Gazette no 510 of July 24, 2009. Lefterache, L.V. 2016. Criminal Law. General Part. Bucharest: Hamangiu Publishing House.

Mitrache, C-tin. and Mitrache, C. 2014. Romanian Criminal Law. General Part. Bucharest: Universul Juridic Publishing House.

Molnar, I. 2001. The plurality of felons in Criminal Law. Bucharest: Academică Publishing House.

Streteanu, F. and Niţu, D. 2018. Criminal Law. General Part. University Course. Vol. 2. Bucharest: Universul Juridic Publishing House.

Udroiu. M. 2017. Criminal Law. General Part. 4th ed. Bucharest: C.H.Beck Publishing House. 